Revista de la red interuniversitaria de estudios sobre las literaturas rioplatenses contemporáneas en Francia

$18 \mid 2018$

El río y la ciudad

\title{
Una mañana en el río
}

\section{Enrique Fernández Domingo}

\section{OpenEdition}

\section{Journals}

\section{Edición electrónica}

URL: http://journals.openedition.org/lirico/5653

DOI: $10.4000 /$ lirico.5653

ISSN: 2262-8339

Editor

Réseau interuniversitaire d'étude des littératures contemporaines du Río de la Plata

\section{Referencia electrónica}

Enrique Fernández Domingo, " Una mañana en el río », Cuadernos LIRICO [En línea], 18 | 2018, Puesto en línea el 13 octubre 2018, consultado el 21 abril 2019. URL : http://journals.openedition.org/ lirico/5653 ; DOI : 10.4000/lirico.5653

Este documento fue generado automáticamente el 21 abril 2019.

\section{(c) (i) (9)}

Cuadernos LIRICO está distribuido bajo una Licencia Creative Commons Atribución-NoComercialSinDerivar 4.0 Internacional. 


\title{
Una mañana en el río
}

\author{
Enrique Fernández Domingo
}

-Buenos días.

-Hola, ¿qué tal?

-Bien. El día se ha levantado fresco.

-Sí, pero con sol. Además no hay viento.

-El río está tranquilo, no hay mucha corriente.

- ¿Te encargas hoy de la seguridad?

-Me toca a mí este sábado.

- ¿Puedo salir con el skiff?

-Sin ningún problema. No te olvides de apuntarlo en el cuaderno de salidas.

-Ok.

Ayudado por otro compañero del Rowing-Club llevamos el barco desde el garaje hasta el agua. Solo en el portón, instalo los remos en las chumaceras, coloco mi pie izquierdo sobre el carro y tomo impulso con el derecho desde el borde de la instalación flotante para reencontrarme con el río.

La tranquilidad de la mañana es perturbada únicamente por el sonido del día a día urbano que circula alrededor del curso de agua.

Sentado en mi pequeña embarcación repito instintivamente los gestos técnicos que me propulsan sobre las aguas del Sena, fluyentes y apacibles, entre las riberas de Ile de Saint Denis y Villeneuve-la-Garenne.

Repliego las piernas, mantengo el equilibrio con mis brazos, oigo el agua entrechocar con las palas de unos remos que he obligado a entrar verticalmente en el río. Tomo impulso gracias a la fuerza que provoca la extensión rápida y violenta de mis extremidades inferiores. A cada empuje de ellas escucho la voz del río abierto en canal por la popa de mi barco. Inspiro el aire suficiente para rellenar de nuevo mis pulmones y poder recomenzar mi domesticación personal y fugaz del Sena.

La velocidad que imprimo al skiff me regala la sensación de ser aceptado por el río, de alcanzar la legitimidad de deslizarme sobre un manto acuático dominado por un esfuerzo que dibuja surcos efímeros en el agua.

Los colores ocres de la vegetación de las orillas se mezclan con los fuertes olores pútridos de los colectores urbanos, el murmullo de la naturaleza desaparece al paso bajo los pilares 
del puente de la autopista A 86, las ondas acuáticas provocadas por el comienzo del vuelo de una garza son absorbidas por los remolinos de las barcazas que se dirigen hacia el puerto de Le Havre, los pequeños astilleros Nord Van Praet acogen las carcasas de viejos paseantes fluviales, las personas más matinales acompañan al río desde sus riberas en este soleado día de finales de otoño.

El ruido del motor de la lancha de seguridad se hace paulatinamente más presente.

-Es hora de volver al pontón. Son las doce y media.

-No te preocupes, ya doy media vuelta.

-¿Qué tal?

-Con un río tan tranquilo es un placer remar.

Una decena de minutos más tarde, de pie sobre el pontón, miro el agua del Sena discurrir ante mí, un río que rencontraré la semana que viene, un río que forma parte de mi vida. Un compañero, un adversario, un lugar de recreo, una vivencia, una imagen, una palabra, un recuerdo...

París, diciembre 2016 